\title{
"TI-SAPPHIRE": CZochralski-PulLed Synthetic Pink SAPPHIRE FROM UNION CARBIDE
}

\author{
By Mary L. Johnson, Meredith E. Mercer, Emmanuel Fritsch, \\ Patricia Maddison, and James E. Shigley
}

\begin{abstract}
One of the most interesting of the commercially available Czochralskipulled synthetic corundums is pink "Ti-sapphire." This material owes its pleasant, somewhat orangy pink color to trivalent titanium, a common trace element in natural sapphires and rubies that occurs here in an unusual oxidation state. Although most of the gemological features are typical of Czochralshi-pulled corundum (gas bubbles or small "pinpoint" inclusions, color zoning), these synthetic sapphires bave distinctive fluorescence and optical spectra. These properties are also due to the chromophore $\mathrm{Ti}^{3+}$.
\end{abstract}

Czochralski-pulled synthetic sapphire was originally grown for technological applications, which require pure crystals with good clarity and even color distribution. Consequently, materials originally intended for such applications can be excellent candidates for use as gems. Czochralskipulled synthetic rubies have been known for a number of years (see, for instance, Nassau and Crowningshield, 1969, and references cited by

\section{ABOUT THE AUTHORS}

Dr. Johnson is a research scientist, and Ms. Maddison is a former senior staff gemologist, in the GIA Gem Trade Laboratory, Santa Monica, California; Ms. Mercer is a former research associate, Dr. Fritsch is former manager, and Dr. Shigley is director of GIA Research, Santa Monica.

See acknowledgments at end of article.

Gems \& Gernology, Vol. 31, No. 3, pp. 188-195.

(C)1995 Gemological Institute of America
Schmetzer, 1986, pp. 14-15|. Major producers of Czochralski-pulled corundum for the gem market include Kyocera (see, e.g., Schmetzer, 1986; Koivula and Kammerling, 1988, 1989); Union Carbide Corporation of Washougal, Washington (Koivula et al., 1992; this article); and Russian sources (Peretti and Smith, 1994). Recently, Czochralski-pulled synthetic ruby and pink sapphire have been in the center of a controversy regarding promotional claims about so-called "recrystallized rubies" (Catalano, 1995a and b; Kammerling et al., 1995b).

Union Carbide is currently using the Czochralski technique to manufacture synthetic sapphires in a variety of colors, specifically for gem applications (figure 1). Although this material has been on the market for a few years (see, e.g., Koivula et al., 1992), we felt that a complete characterization of the various colors of Czochralskipulled material was desirable, as none has been published to date. We began our study with the 
relatively new pink synthetic Ti-sapphires (figure 2), because-since they are colored by titanium (Ti) rather than chromium $(\mathrm{Cr})$-identification of this material is more straightforward than for many other colors of Czochralski-pulled corundum. We have adopted the term (synthetic) Ti-sapphire, because that is the name by which it is known in the laser field.

Although the material in this study comes from Union Carbide, synthetic Ti-sapphire from other sources may be on the market, including material from China ("Pink synthetic sapphire," 1991).

\section{BACKGROUND}

The Czochralski crystal-growth technique, also known as pulling from the melt, consists of touching a starting-material "seed" to the surface of molten crystal constituents within the hot zone of a furnace, and then withdrawing the seed crystal very slowly, so that only the melt that wets the seed crystal solidifies. The newly solidified material is still in contact with the remaining melt, which continues to solidify as the seed-is gradually pulled farther away. This results in a single-crystal rod of high-quality material. Czochralski pulling was originally used to make samples of pure metals (e.g., bismuth); today, it is also used for the production of low-strain, lowdefect crystals for technical applications, and for purposes where the growth direction of the resultant boule is important (as in the case of synthetic alexandrite; see, e.g., Kane, 1987). A general introduction to Czochralski pulling is given by Nassau (1980), and more detail can be found in books by Brice (1986), Sloan and McGhie (1988), and Arend and Hulliger (1989); the original publication on this process is by Czochralski (1918). Morita et al. (1993) describe Czochralski growth conditions for synthetic sapphire, especially with regard to the formation of included bubbles in the growing crystal.

Pink synthetic Ti-sapphire is especially useful for laser applications, because its electronic and optical properties allow it to produce highenergy laser light over a wide range of frequencies in and near the visible range (Fletcher and Bischel, 1990). Although it is grown primarily by the Czochralski process, it has also been grown by both the flame-fusion and flux methods (see, e.g., Moncorgé et al., 1988). The coloring agent is trivalent titanium $\left(\mathrm{Ti}^{3+}\right)$, and the quality of this material for laser purposes is determined in part

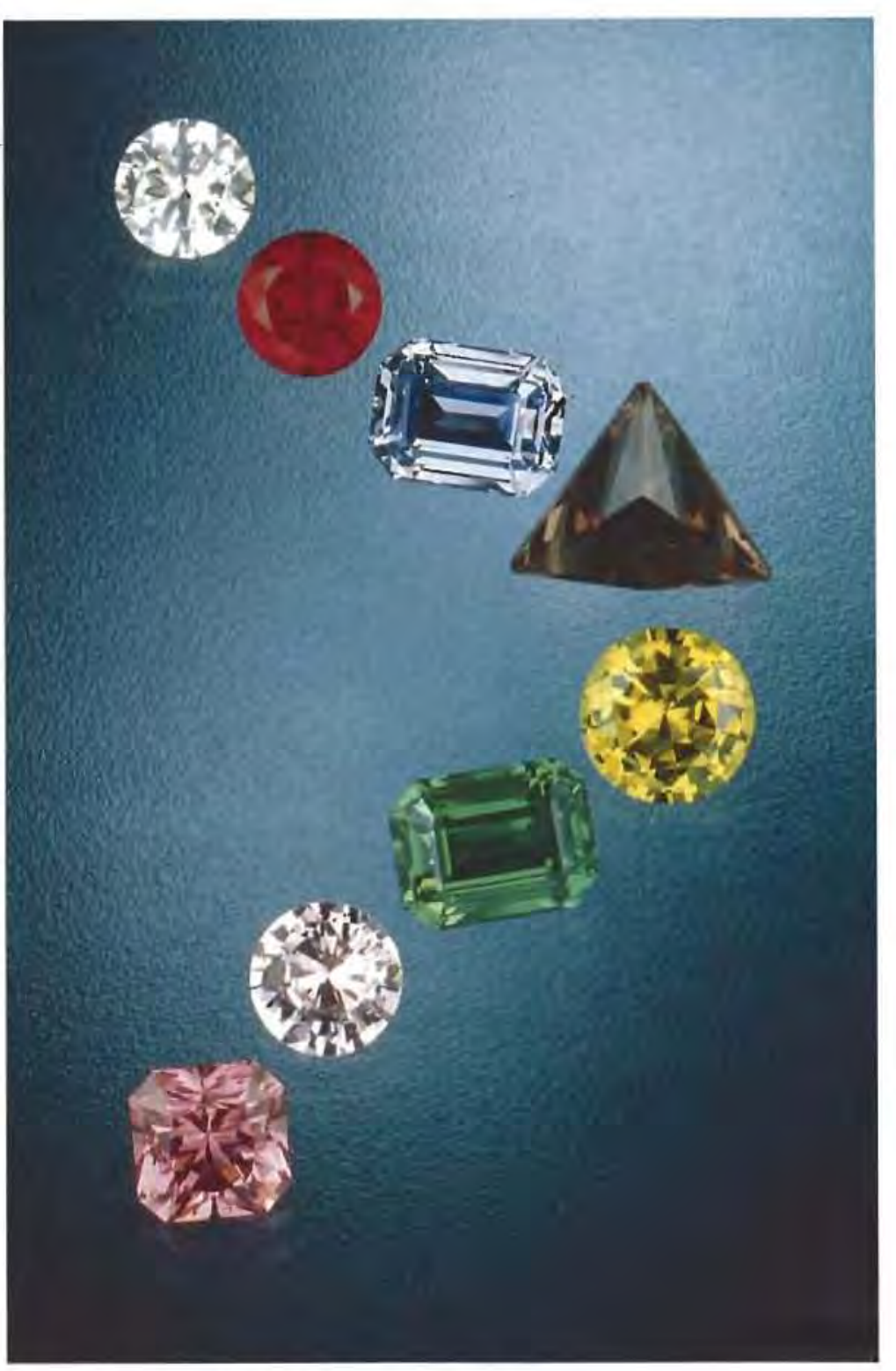

Figure 1. Union Carbide Corporation has produced many colors of synthetic sapphire by the Czochralski-pulling technique. Some examples include (from lower left): annealed pink (1.44 ct), as-grown pink (0.87 ct), green (2.28 ct), yellow $(1.66 \mathrm{ct})$, brown $(4.92 \mathrm{ct})$, violetish blue $(2.20 \mathrm{ct})$, red $(1.18 \mathrm{ct})$, near colorless $(0.89 \mathrm{ct})$. Photo (C) GIA and Tino Hammid.

by oxidized $\mathrm{Ti}^{4+}$ (the common oxidation state of titanium in terrestrial minerals): the lower the $\mathrm{Ti}^{4+}$ concentration, the higher the laser efficiency. Because of this, synthetic Ti-sapphire is usually annealed under reducing conditions (see, e.g., Moulton, 1986), which converts residual $\mathrm{Ti}^{4+}$ impurity to $\mathrm{Ti}^{3+}$.

\section{MATERIALS AND METHODS}

We examined nine faceted samples and five samples of rough material in two general colors: slightly orangy pink and purplish pink. The more satu- 
rated, slightly orangy pink samples (including material described by Union Carbide as having been annealed in a reducing atmosphere subsequent to crystal growth) are labeled "annealed" throughout this article. The paler, more purplish pink faceted sample resembles in all particulars the sample of as-grown rough material provided by Union Carbide, and these two samples are labeled "as grown" below.

Gemological examination of the faceted samples was performed as follows. Face-up colors were described by trained observers using both daylight-equivalent fluorescent and incandescent light sources; in no case (faceted or "rough") was any significant change in hue observed between the two light sources. These colors were described in terms of predominant and modifier hues (such as "purplish pink"). The refractive index (R.I.) of each was measured with a Duplex II refractometer and a filtered, near-monochromatic, Na-equivalent light source. Specific gravity was determined by the hydrostatic method. Fluorescence was observed by trained gemologists in a darkened room using a standard short-wave/long-wave ultraviolet lamp. Polarization behavior was noted using a GIA GEM Illuminator polariscope, and absorption spectra were observed using a Beck handheld spectroscope on a GIA GEM Instruments base. To examine the internal features, we used a standard gemological microscope with various lighting techniques. For part of this examination, the samples were immersed in methylene iodide (diiodomethane). We tested for visible luminescence (often called transmission luminescence) in two ways: (1) with the loose stone on the spectroscope base; and (2) through the microscope, using a fiber-optic illuminator with a halogen light bulb as illumination source.

Trace-element chemistry was determined by energy-dispersive X-ray fluorescence (EDXRF) spectroscopy, using a Tracor Xray (now Spectrace Instruments) Spectrace 5000 with a rhodium-target X-ray tube. We performed quantitative analyses using the Fundamental Parameters method of Criss and Birks (see, e.g., Jenkins, 1980) with two sets of operating conditions: first, with an X-ray tube voltage of $15 \mathrm{kV}$, a $15-\mathrm{mA}$ tube current, no filter, and a live time of 200 seconds, for determination of low-atomic-weight elements; and second, with an X-ray tube voltage of $25 \mathrm{kV}, 25 \mathrm{~mA}$

TABLE 1. Gemological properties of synthetic Ti-sapphires and other natural and synthetic pink sapphires.

\begin{tabular}{|c|c|c|c|c|}
\hline Property & $\begin{array}{l}\text { "Annealed" } \\
\text { synthetic Ti-sapphire }\end{array}$ & $\begin{array}{l}\text { "As-grown" } \\
\text { synthetic Ti-sapphire }\end{array}$ & $\begin{array}{c}\text { Natural } \\
\text { pink sapphire }\end{array}$ & $\begin{array}{l}\text { Cr-doped Czochralski } \\
\text { synthetic pink sapphire }\end{array}$ \\
\hline Color & Pink to orangy pink & Light pink & Pink to purple pink & Pink \\
\hline Color distribution & Even to uneven & Even & (Variable) & Even \\
\hline Clarity & Transparent & Transparent & Transparent lo opaque & Transparent \\
\hline Pleochroism (e) & Yellow to orangy pink & Near colorless & Orangy pink to orange-pink & Orangy pink \\
\hline Pleochroism (o) & Light pink to pinkish red & Light purplish pink & Purplish pink lo purple-pink & Purplish pink \\
\hline Optic character & Uniaxial negalive & Uniaxial negative & Uniaxial negative & Uniaxial negative \\
\hline Color filter reaction & Usually red (1 none, 1 orangy pink) & Greenish yellow & Mioderate pink to dark red & Red \\
\hline \multicolumn{5}{|l|}{ Transmission } \\
\hline luminescence & None to moderate red & Slight scattering & Usually none, seldom red & None \\
\hline R.I. $\left(n_{e}\right)$ & $1.759-1.760$ & 1.760 & $1.757-1.771$ & 1.760 \\
\hline R.I. $\left(n_{0}\right)$ & $1.767-1.769$ & 1.768 & $1.765-1.779$ & 1.768 \\
\hline Birefringence & $0.008-0.009$ & 0.008 & 0.008 & 0.008 \\
\hline Specific gravity & $3.99-4.01$ & 4.00 & $3.95-4.10$ & $3.99-4.01$ \\
\hline $\begin{array}{l}\text { Luminescence } \\
\text { to short-wave UV }\end{array}$ & $\begin{array}{l}\text { Weak to moderate blue, } \\
\text { slightly to very chalky }\end{array}$ & $\begin{array}{l}\text { Strong blue, } \\
\text { slightiy chalky }\end{array}$ & Faint to weak orange to red & $\begin{array}{l}\text { Moderate red, not chalky; } \\
\text { moderate pink, chalky }\end{array}$ \\
\hline $\begin{array}{l}\text { Spectroscope } \\
\text { spectrum (nm) }\end{array}$ & $\begin{array}{l}410 \text { cutoff, weak } 470,500 \text { band, } \\
570 \text { band, } 670-690 \text { cutoff }\end{array}$ & No sharp bands & $\begin{array}{l}468.5,475,476.5,659.2 \\
668,692.8,694.2 \text { lines }\end{array}$ & $\begin{array}{l}468.5,475,476.5,659.2 \\
668,692.8,694.2 \text { lines }\end{array}$ \\
\hline Inclusions & Usually pinpoints; gas bubbles in one case & Pinpoints & (Variabie) & None seen \\
\hline Immersion & Color banding has gradual borders, if visible & (Too laint to see) & (Variable) & No leatures seen \\
\hline Source of data & 8 laceted samples, this study & 1 faceled sample, this study & Webster (1994), GIA (1988) & $\begin{array}{l}6 \text { faceled samples, new } \\
\text { data }^{\text {a }}\end{array}$ \\
\hline
\end{tabular}

a Testing pertormed by GIA Gem Trade Laboratory using same meihods as for the Union Carbide synthelic Ti-sapphire. Samples loaned by Jery Manning Opal Co., New York Cilly. 
tube current, aluminum filter, and live time of 200 seconds, for determination of intermediateatomic-weight elements. Standards included tsavorite (for $\mathrm{Al}, \mathrm{Si}$ ), garnet (for $\mathrm{Al}, \mathrm{Si}, \mathrm{Mn}, \mathrm{Fe}$ ), and synthetic corundum (for $\mathrm{Al}$ ); yields for $\mathrm{Ca}, \mathrm{Ti}, \mathrm{V}$, $\mathrm{Cr}$, and $\mathrm{Ga}$ were extrapolated from those for other elements. The standards were calibrated against microprobe compositions determined by Paul Carpenter at the California Institute of Technology. Ti is reported as weight percent titanium dioxide $\left(\mathrm{TiO}_{2}\right.$; that is, as $\left.\mathrm{Ti}^{4+}\right)$, although it primarily occurs as $\mathrm{Ti}_{2} \mathrm{O}_{3}\left(\mathrm{Ti}^{3+}\right)$ in synthetic Ti-sapphire.

Two polished samples of annealed and as-grown "rough" (288B and 297B) were aiso analyzed using a five-crystal JEOL Model 733 electron microprobe operating at a beam accelerating potential of $15 \mathrm{kV}$, a current of $35 \mathrm{nA}$, and a spot size between 10 and $25 \mu \mathrm{m}$. Standards include: $\mathrm{Al}_{2} \mathrm{O}_{3}$ for $\mathrm{Al}$, anorthite for $\mathrm{Ca}, \mathrm{TiO}_{2}$ for $\mathrm{Ti}, \mathrm{Cr}_{2} \mathrm{O}_{3}$ for $\mathrm{Cr}$, and synthetic fayalite for Fe. Total iron was calculated as $\mathrm{FeO}$, and total titanium as $\mathrm{TiO}_{2}$. Ga was not detected in these samples. The data were corrected using the program CITZAF (Armstrong, T988). Each specimen was analyzed at three randomly selected locations.

\begin{tabular}{|c|c|c|}
\hline $\begin{array}{l}\text { Chatham flux synthetic } \\
\text { pink sapphire }\end{array}$ & $\begin{array}{l}\text { Kashan Ilux synthetic } \\
\text { pink sapphire }\end{array}$ & $\begin{array}{l}\text { Flame-fusion synthetic } \\
\text { pink sapphire }\end{array}$ \\
\hline Purplish pink & Purplish pink & Pink to purplish pink \\
\hline (Not reported) & Even & Usually uneven \\
\hline (Not reported) & Transparent & Transparent \\
\hline Orangy pink & Orangy pink & Orangy pink to orange-pink \\
\hline Purplish pink & Purplish pink & Purplish pink to purple-pink \\
\hline Uniaxial negative & Uniaxial negative & Uniaxial negalive \\
\hline Strong red & Moderale red & Moderate pink to dark red \\
\hline (Not reported) & (Not reported) & (Not reporter') \\
\hline 1.759 & 1.760 & 1.762 \\
\hline 1.768 & 1.769 & 1.770 \\
\hline 0.009 & 0.009 & 0.008 \\
\hline $3.99-4.00$ & 4.00 & About 4.00 \\
\hline $\begin{array}{l}\text { Slrong orangy red, } \\
\text { weakly } 10 \text { moderately chalky }\end{array}$ & Moderate to strong red & Moderate to strong red \\
\hline $\begin{array}{l}\text { Strong orangy red, } \\
\text { wieakly to moderately chalky }\end{array}$ & Moderate red & Weak orangy red \\
\hline $\begin{array}{l}468.5,475,476.5,659.2 \\
668,692.8,694.2 \text { lines }\end{array}$ & $\begin{array}{l}468.5,475,476.5,659.2 \\
668,692.8,694.2 \text { lines }\end{array}$ & $\begin{array}{l}468.5,475,476.5,659.2 \\
668,692.8,694.2 \text { lines }\end{array}$ \\
\hline $\begin{array}{l}\text { Flux, platinum metal, fingerprints } \\
\text { (Not reported) }\end{array}$ & $\begin{array}{l}\text { Wispy veils, rain, stringers } \\
\text { (Not reported) }\end{array}$ & $\begin{array}{l}\text { Gas bubbles, etc. } \\
\text { Color banding } \\
\text { (usually pronounced), etc. }\end{array}$ \\
\hline Kammerling et al. (1994) & $\begin{array}{l}\text { Henn and Schrader (1985), } \\
\text { Kammerling et al. (1995a) }\end{array}$ & Webster (1994), GIA (1988) \\
\hline
\end{tabular}

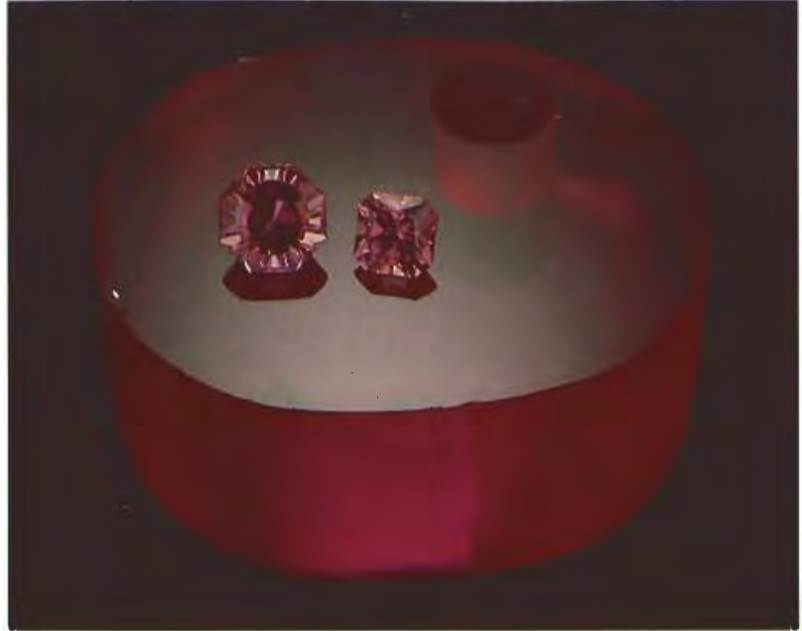

Figure 2. These two annealed synthetic Ti-sapphires (2.97 ct and $1.44 \mathrm{ct}$ ) were cut from material similar to the 343.33-ct section of a boule on which they are seated. Courtesy of Union Carbide Corp.; photo by Robert Weldon.

We recorded UV-visible spectra on a Hitachi U-4001 spectrophotometer, using a resolution of $1 \mathrm{~nm}$. To better understand the causes of color, we prepared crystallographically oriented pieces of some of our specimens so that we could obtain polarized absorption spectra. For this purpose, we selected three pieces of "rough" (two annealed, and one as-grown). From each specimen, we cut and polished a flat, parallel-windowed section containing the optic axis direction, as determined by the X-ray precession method. Polarized spectra were obtained using calcite polarizers.

\section{RESULTS}

Physical and Optical Properties. For the nine faceted samples, table 1 summarizes the gemological properties and compares them to properties of natural pink sapphires, Czochralski-pulled synthetic pink sapphires colored by chromium, Chatham flux-grown synthetic pink sapphires, Kashan flux-grown synthetic sapphires, and commercially available flame-fusion synthetic pink sapphires.

A number of these properties distinguish synthetic Ti-sapphire from natural pink sapphires and from synthetic pink sapphires colored by chromium. These include its unusual lack of fluorescence to long-wave UV radiation, and especially its chalky blue fluorescence to short-wave 




Figure 3. Extremely small gas bubbles can be seen in this 2.97-ct Czochralski-pulled Ti-sapphire at 50x magnification. In the other samples we examined, these "pinpoints" were too small to be resolved as gas bubbles. Photomicrograph by John I. Koivula.

UV. The spectra of synthetic Ti sapphire as seen with a handheld spectroscope also appear unusually weak, with no chromium absorption or emission bands seen. These properties do not distinguish synthetic Ti-sapphires produced by Czochralski pulling from Ti-sapphires synthesized by other means; however, there are no known pink natural gem sapphires that owe their color to titanium alone.

Magnification. Inclusions. With the fiber-optic light, we observed small "pinpoint" inclusions (high-relief bubbles) in all of the faceted annealed samples examined. In one sample (figure 3), these "pinpoints" were large enough to be resolved as gas bubbles. The as-grown faceted sample also contained numerous pinpoint inclusions.

Features Seen with Immersion. We observed very subtle color banding in two annealed samples, with the regions of different colors having diffuse boundaries /seen with immersion in methylene iodide) or color zoning visible only in polarized light. We did not discern any color zoning in the other annealed samples, or in the as-grown synthetic Ti-sapphire. Although Nassau as well as Crowningshield (1969) and Schmetzer (1986) mention finely striated curved color banding in Czochralski-pulled synthetic sapphires, no such bands were observed in these samples. We looked for twinning, but did not see any.

Trace-Element Chemistry. The quantitative measurements made by EDXRF analysis for calcium $(\mathrm{Ca}), \mathrm{Ti}$, vanadium (V), chromium $(\mathrm{Cr})$, and iron (Fe) are reported in table 2. These elements are all commonly found in natural and synthetic corundums. We looked for gallium in all samples, but found no evidence of it. We also examined two of the samples (annealed 288B and asgrown 297B/ with the electron microprobe, which yielded the same compositions as did EDXRF. Both analytical techniques are precise to $\pm 0.01 \mathrm{wt}$. \% , based on counting statistics.

All of the annealed synthetic Ti-sapphires were found to contain titanium /ranging from 0.06 to $0.25 \mathrm{wt} . \% \mathrm{TiO}_{2}$ ) and iron (in one case, as much as 0.04 wt. \% FeOl. The two as-grown synthetic Ti-sapphires revealed less titanium on average (0.04 to $0.08 \mathrm{wt} \%$ titanium as $\mathrm{TiO}_{2}$ ) than the annealed samples, but they also have less saturated colors.

UV-Visible Spectroscopy. Pairs of polarized absorption spectra in the $\mathrm{E} \perp c$ (that is, incident light polarized perpendicular to the optic axis) and $E \|_{C}$

TABLE 2. Partial chemical analyses of 11 synthetic Ti-sapphires. ${ }^{2}$

\begin{tabular}{|c|c|c|c|c|c|c|c|c|c|c|c|}
\hline \multirow[b]{2}{*}{ Trace elements ${ }^{b}$} & \multicolumn{7}{|c|}{ Annealed (slighily orangy pink) } & \multirow[b]{2}{*}{$\begin{array}{c}\text { №. } 1532 \\
(542.34 \mathrm{ct})\end{array}$} & \multirow[b]{2}{*}{$\begin{array}{l}\text { No. } 1637 \\
(1.07 \mathrm{ct})\end{array}$} & \multicolumn{2}{|c|}{ As-grown (purplish pink) } \\
\hline & $\begin{array}{c}\text { No. } 0078 \\
(1.44 \mathrm{ct})\end{array}$ & $\begin{array}{l}\text { No. } 0079 \\
(2.97 \mathrm{ct})\end{array}$ & $\begin{array}{l}\text { No. } 288 B^{C} \\
(11.41 \mathrm{Cl})\end{array}$ & $\begin{array}{l}\text { No. } 288 \mathrm{C} \\
(8.40 \mathrm{ct})\end{array}$ & $\begin{array}{l}\text { No. 288D } \\
(11.34 \mathrm{ct})\end{array}$ & $\begin{array}{c}\text { No. } 1530 \\
\text { (207.30 ct) }\end{array}$ & $\begin{array}{c}\text { No. } 153 \uparrow \\
(522.57 \mathrm{ct})\end{array}$ & & & $\begin{array}{l}N_{0.297 B^{C}} \\
(10.37 \mathrm{ct})\end{array}$ & $\begin{array}{l}\text { No. } 1636 \\
(0.87 \mathrm{ct})\end{array}$ \\
\hline $\mathrm{CaO}$ & $\mathrm{tr}$ & tr & tr & $\mathrm{tr}$ & 0.01 & Ir & $\mathrm{tr}$ & ir & 0.02 & $\operatorname{tr}$ & 0.01 \\
\hline $\mathrm{TiO}_{2}$ & 0.18 & 0.16 & 0.10 & 0.12 & 0.11 & 0.13 & 0.06 & 0.16 & 0.25 & 0.08 & 0.04 \\
\hline $\mathrm{V}_{2} \mathrm{O}_{3}$ & nd & $\pi$ & $\operatorname{tr}$ & nd & nd & nd & nd & nd & $\mathrm{tr}$ & nd & $\mathrm{tr}$ \\
\hline $\mathrm{Cr}_{2} \mathrm{O}_{3}$ & nd & nd & $\operatorname{tr}$ & nd & $\mathrm{tr}$ & nd & nd & nd & tr & nd & nd \\
\hline $\mathrm{Fe} 0$ & $\mathrm{tr}$ & $\operatorname{tr}$ & $\operatorname{tr}$ & $\mathrm{tr}$ & $\mathrm{tr}$ & 0.01 & $\pi$ & nd & 0.04 & $\operatorname{tr}$ & tr \\
\hline
\end{tabular}




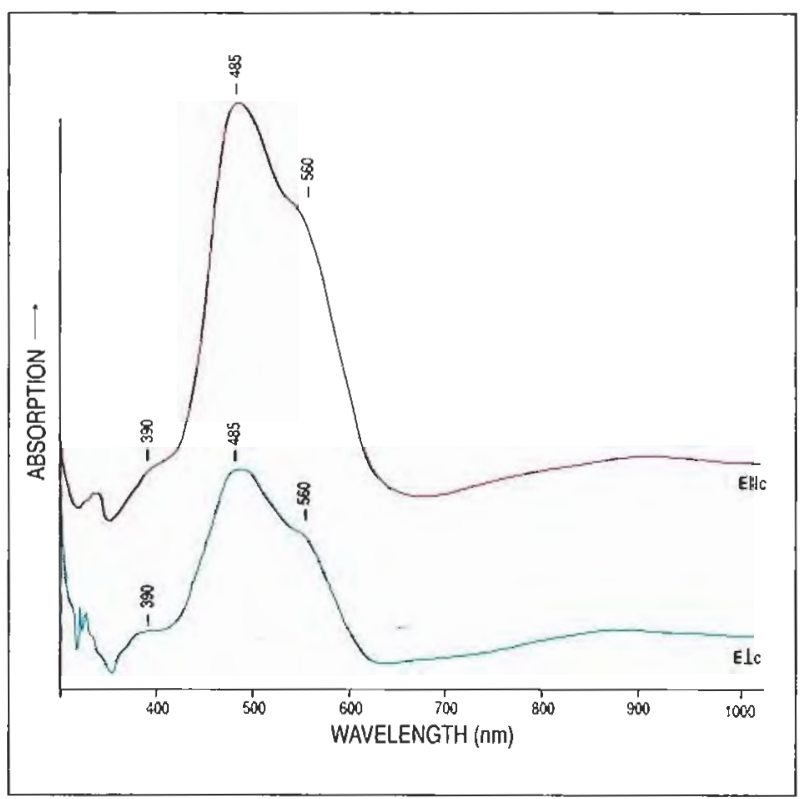

Figure 4. The polarized absorption spectra from the UV-visible spectrophotometer for annealed (slightly orangy pink) synthetic Ti-sapphire reveal important features at 485, 560, and 390 $\mathrm{nm}$ (sample 1532). The peaks at 485 and $560 \mathrm{~nm}$ provide evidence of the presence of $\mathrm{Ti}^{3+}$ and have not been found to date in natural sapphires.

(that is, incident light polarized parallel to the optic axis) directions are shown in figures 4 and 5 for annealed (slightly orangy) and as-grown (purplish) pink sapphire, respectively.

Four pieces of slightly orangy pink sapphire "rough" and four faceted annealed synthetic Tisapphires showed very similar (unpolarized) UVvisible spectra, with a prominent peak centered at approximately $485 \mathrm{~nm}$, a strong shoulder at roughly $560 \mathrm{~nm}$, and a smaller peak centered at about $390 \mathrm{~nm}$.

The spectrum of the as-grown piece of synthetic pink sapphire, which looks purplish rather than orangy, superimposes the $485 / 560$ pair on a weak but very broad band with its maximum at about $840 \mathrm{~nm}$ (figure 5). This feature causes the 560 shoulder to appear to be almost equal in size to the 485 peak in the $\mathrm{E} \perp \mathrm{c}$ direction.

\section{DISCUSSION}

Separation from Natural Sapphire. In general, Czochralski-pulled corundum may be separated from very fine, inclusion-free natural examples with great difficulty, or only by advanced testing methods. In many stones, inclusions are not visible, or they are so small as to be ambiguous in interpretation-and one cannot conclude that a stone is synthetic simply because it is "too good." In the case of synthetic Ti-sapphire, however, some of the gemological properties are different from those of natural pink sapphires because synthetic Ti-sapphire contains $\mathrm{Ti}^{3+}$, which has not been found to date in pink natural sapphires, and has little or no $\mathrm{Cr}^{3+}$. These distinctive properties include: no luminescence to long-wave UV radiation; chalky blue luminescence to short-wave UV radiation (due to octahedral $\mathrm{Ti}^{4+} \mathrm{O}_{6}$ impurities: see below); and a faint but different spectrum as seen with a spectroscope (especially with regard to the lack of chromium emission lines in the red). Also, the samples in our study contained "pinpoint" inclusions, which were sometimes resolvable as gas bubbles. In the final analysis, when there are not enough gemological clues to identify an unknown stone unambiguously, a synthetic Ti-sapphire can be reliably separated from a pink sapphire colored by chromium by means of its chemistry or UV-visible absorption spectrum.

Causes of the Colors. Natural pink sapphires, like rubies, owe their color to chromium (Nassau, 1980; Fritsch and Rossman, 1988). Broad chromium

Figure 5. The polarized absorption spectra for as-grown (purplish pink) synthetic Ti-sapphire (a separate slice of sample 297B) superimpose the 485/560 pair on a weak but broad band with a maximum at about $840 \mathrm{~nm}$. This latter peak is consistent with Fe-Ti charge transfer.

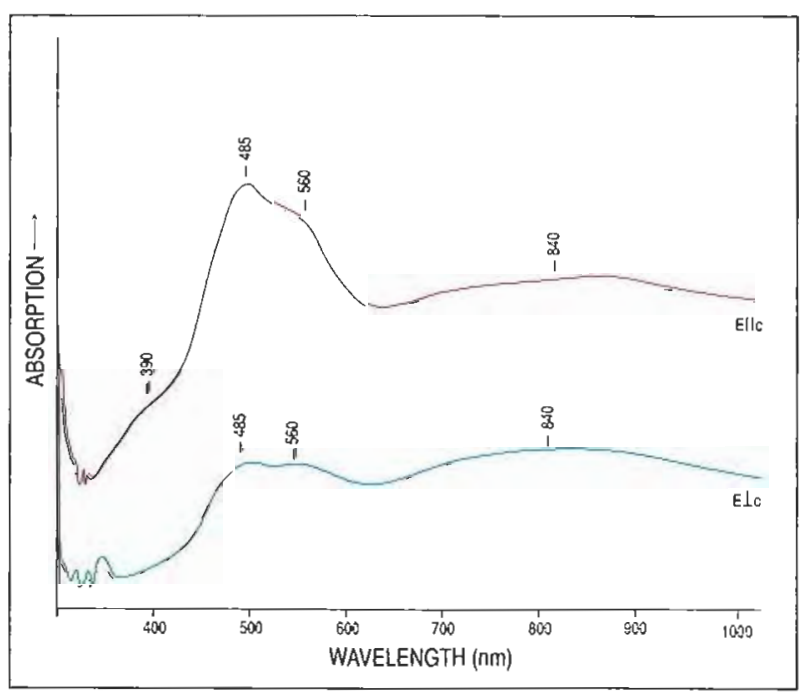


peaks in natural pink sapphires and rubies occur at roughly $410 \mathrm{~nm}$ and $550 \mathrm{~nm}$, whereas the peaks in synthetic Ti-sapphires are seen at approximately 390,485 , and $560 \mathrm{~nm}$. The natural orangy pink sapphires that we have seen, and that have been reported in the literature (Schmetzer et al., 1983; Fritsch and Rossman, 1988|, contain chromium and iron (sometimes determined to be $\mathrm{Fe}^{3+}$ ) or chromium and magnesium $\left(\mathrm{Mg}^{2+}\right)$. Therefore, they show chromium spectra in addition to other features.

Annealed Pink. The coloration of the slightly orangy pink (annealed) synthetic sapphires we examined is due to trivalent titanium: The peaks seen in the UV-visible spectra at 485 and $560 \mathrm{~nm}$ are typical in position and polarization for $\mathrm{Ti}^{3+}$ in corundum (McClure, 1962; Townsend, 1968; Eigenmann et al., 1972; Moskvin et al., 1980; Moulton, 1986; again, see figures 4 and 5.) The small peak at $390 \mathrm{~nm}$ is not seen in most materials colored by $\mathrm{Ti}^{3+}$, and has been attributed to defects (Bessonova et al., 1976) or included $\mathrm{Al}_{2} \mathrm{TiO}_{5}$ (Winkler et al., 1966).

As-Grown Pink. An additional broad feature is found in the spectrum of as-grown synthetic Tisapphire at about $840 \mathrm{~nm}$ (figure 5); this peak is broader at lower wavelengths in the $E \perp c$ direction. The position and polarization behavior of this peak is consistent with Fe-Ti charge transfer, as seen in Verneuil synthetic sapphires doped with both $\mathrm{Fe}$ and $\mathrm{Ti}$ (see, for instance, Eigenmann et al., 1972). (However, Moulton [1986] has described this peak as due to charge transfer between $\mathrm{Ti}^{3+}$ and $\mathrm{Ti}^{4+}$.) Only trace amounts of iron-such as those present in our samples, according to the EDXRF results in table 2-would be necessary to account for this broad feature, which would disappear with reduction-annealing (as in the Eigenmann et al. study, and as seen in our samples).

Luminescence Behavior. The blue fluorescence to short-wave UV radiation observed in our samples is virtually identical to that described by Blasse and Verweij (1990) for Ti-doped synthetic sapphires. These authors showed that this emission is due to charge-transfer transitions in a titanate group, that is, $\mathrm{Ti}^{4+}$ in octahedral coordination in a site in the corundum structure that is normally empty. (This group is usually designat- ed $\left.\mathrm{Ti}^{4+} \mathrm{O}_{6}.\right)$ We therefore believe that the fluorescence behavior of our samples, both annealed and as-grown, is due to these titanate groups, which are present as impurities because of the titanium doping. The fluorescence is more pronounced in the as-grown samples, which have greater amounts of $\mathrm{Ti}$ in oxidized species.

The red transmission luminescence (i.e., luminescence excited by transmitted visible light) observed in our annealed samples is due to $\mathrm{Ti}^{3+}$. Although some rubies and pink sapphires colored by $\mathrm{Cr}^{3+}$ also luminesce, and can be used for laser materials ("ruby" lasers), details of the emission spectra for the two chromophores are quite different.

\section{SUMMARY AND CONCLUSION}

Czochralski-pulled synthetic corundum is not as common in the marketplace as flame-fusion synthetic corundum, but it can be far more difficult to separate from clean natural material. Identification is easiest for a Czochralski-pulled material for which the cause of color is different from that in the corresponding natural stone. In the case of (possibly orangy) pink synthetic sapphires colored by $\mathrm{Ti}^{3+}$, the faint absorption spectrum lacking "chrome lines" and the unusual fluorescence behavior are highly suspicious. $\mathrm{Ti}^{3+}$ is responsible for the absorption spectrum land red transmission luminescence), and an oxidized interstitial titanium impurity causes the short-wave UV fluorescence. When an unknown stone is suspected of being synthetic Ti-sapphire, a cautious gemologist may wish to confirm this by using high magnification to search for included gas bubbles; failing that, advanced testing may be in order.

Acknowledgments: The authors thank Milan Kokta of Union Carbide Corporation, Washougal, Washington, and Gerry Manning of Manning Opal Company, New York City, for providing samples and information; Paul Carpenter and Larry Henling of the California Institute of Technology, Pasadena, for microprobe analyses and $X$-ray diffraction precession photography, respectively; and, from GIA, Sam Muhlmeister for additional EDXRF analyses and help with the $U V$ visible spectrophotometry, Scott Hemphill for processing UV-visible spectra, and Martin Chung and Joe Garcia for faceting some of the samples used in this study. Dino DeGhionno and Philip Owens, of the GIA Gem Trade Laboratory, kindly provided additional gemological characterization of the samples. 


\section{REFERENCES}

Arend H., Hulliger J. (1989) Crystal Growth in Science and Technology. Plenum Press, New York.

Armstrong J.T. (1988) Quantitative analysis of silicate and oxide materials: Comparison of Monte Carlo, ZAF, and $\phi($ rz) procedures. In D. E. Newbury, Ed., Microbeam Analysis-1988, San Francisco Press, San Francisco, CA, pp. 239-246.

Bessonova T.S., Stanislavskii M.P., Khaimov-Malkov V.Ya (1976) Effect of healt treatment and irradiation on absorption spectra of $\mathrm{Ti}$ and Si corundum. Optical Spectroscopy, Vol. 4l, No. 1, pp. 87-88.

Blasse G., Verweij J.W.M. (1990) The luminescence of titaniun as sapphire laser material. Materials Chemistry and Physics, Vol. 26, pp. 131-173.

Brice J.C. (1986) Crystal Growth Processes. Blackie and Son, Glasgow.

Catalano D.A. \{1995a) New created gem irks veteran growers. National Jeweler, Vol. 39, No. 3, February 1, pp. 1, 146.

Catalano D.A. (1995b) Gem recrystallization to fore National Jeweler, Vol. 39, No. 6, March 16, 1995, pp. 3, 95.

Czochralski J. (1918) Ein neues Verfahren zur Messung der Kristallisationsgeschwindigkeit der Metalle. Zeitschrift für physikalische Chemie, Vol. 92, pp. 219-221.

Eigenmann K., Kurtz K., Günthard Hs.H. (1972) Solid state reactions and defects in doped Verneuil sapphire. III. Systems $\alpha-\mathrm{Al}_{2} \mathrm{O}_{3}: \mathrm{Fe}, \alpha-\mathrm{Al}_{2} \mathrm{O}_{3}: \mathrm{Ti}$, and $\alpha-\mathrm{Al}_{2} \mathrm{O}_{3}:(\mathrm{Fe}, \mathrm{Ti})$. Helvetica Physica Acta, Vol. 45, pp. 452-480.

Fletcher P.W., Bischel W.K. (1990) Titanium-sapphire: Todày's hot laser. $R e D$ Magazine, Vol. 32, No. 5, pp. 124-128.

Fritsch E., Rossman G.R. (1988) An update on color in gems. Part 3: Colors calused by band gaps and physical phe nomena. Gems et Gemology, Vol. 24, No. 2, pp. 81-102.

Gemological Institute of America [GIA] (1988) Gem Reference Guide. Gemological Institute of America, Santa Monica, CA.

Henn U., Schrader H.-W. (1985) Some aspects of identification of Kashan synthetic rubies. Journal of Gemmology, Vol. 19, No. 6, pp. 469-478.

Jenkins R. (1980) An Introduction to X-ray Spectrometry. Heyden and Sons, Philadelphia, PA.

Kammerling R.C., Koivula J.I., Fritsch E. (1994) An examination of Chatham flux-grown synthetic pink sapphires. Journal of Gemmology, Vol. 24, No. 3, pp, 149-154.

Kammerling R.C., Koivula J.I., Fritsch E., Johnson M.L., DeGhionno D.G. (1995a) Gem news: Faceted Kashan synthetic rubies and sapphires. Gems e Gemology, Vol. 31 , No. 1, p. 70

Kammerling R.C., Koivula J.1., Fritsch E., Johnson M.L., DeGhionno D.G. (1995b) Gem news: Update on "recrystallized" corundum. Gems e) Gemology, Vol. 31, No. 2, pp. 135-136.

Kane R.E. (1987) Inamori synthetic cat's-eye alexandrite. Genzs es Gemology, Vol. 23, No. 3, pp. 158-161.
Koivula J.1., Kammerling R.C. (1988) A gemological look at Kyocera's new synthetic star ruby. Gems \&) Gemology, Vol. 24, No. 4, pp. 237-240.

Koivula J.l., Kammerling R.C. (1989) The gemmology of Kyocera's new synthetic star ruby. South African Gemmologist, Vol. 3, No. 2, pp. 5-14.

Koivula J.1., Kammerling R.C., Fritsch E. (1992) Gem newsTitanium-doped synthetic pink sapphire. Gems 4 Gemology, Vol. 28, No. 1, p. 66.

McClure D.S. (1962) Optical spectra of transition metal ions in corundum. Journal of Chemical Physics, Vol. 36, No. 3, pp. 2757-2779.

Moncorgé R., Boulon G., Vivien D., Lejus A. M., Collongues R., Djévahirdjian V., Djévahirdjian K., Cagnard R. (1988) Optical properties and tunable laser action of Verneuilgrown single crystals of $\mathrm{Al}_{2} \mathrm{O}_{3}: \mathrm{Ti}^{3+}$. IEEE Journal of Quantum Electronics, Vol. 24, No. 6, pp. 1049-1051.

Morita S., Sekiwa H., Toshima H., Miyazawa Y. (1993) The growth of alumina single crystals by the Czochralski method. Journal of the Ceramic Society of Japan, Vol. 101, pp. 108-112.

Moskvin N.A., Sandulenko V.A., Sidorova E.A. (1980) Color centers and luminescence in corundum crystals containing titanium. Journal of Applied Spectroscopy, Vol. 32, No. 6, pp. 592-596.

Moulton P.F. (1986) Spectroscopic and laser characteristics of Ti: $\mathrm{Al}_{2} \mathrm{O}_{3}$. Journal of the Optical Society of America, Series B, Vol. 3 , No. 1, pp. 125-133.

Nassau K. (1980) Gems Made by Man. Chilton Book Co., Radnor, PA.

Nassau K., Crowningshield R. (1969) The synthesis of ruby. Part three: The mystery of "reconstructed" ruby solved. Lapidary Iournal, Vol. 23, No. 3, pp. 440-444, 446.

Peretti A., Smith C.P. (1994) Letters to the editor. Journal of Gemmology, Vol. 24, No. 1, pp. 61-63.

"Pink synthetic sapphire" (1991) Jewellery News Asia, No. 84, August 1991, p. 116

Schmetzer K. (1986) Natürlich und synthetische Rubine: Eigenschaften und Bestimmung. E. Schweitzerbart'sche Verlagsbuchlandlung (Nägele u. Obermiller), Stuttgart.

Schmetzer K., Bosshart G., Hänni H.A. (1983) Naturally-colored and treated yellow and orange-brown sapphires. Journal of Gemmology, Vol. 18, pp. 607-622.

Sloan G.I., McGhie A.A. (1988) Techniques of Melt Crystallization. Techniques of Chemistry, Vol, 19, Ed. by A. Weissberger, John Wiley, New York.

Townsend M.G. (1968) Visible charge transfer in blue sapphire. Solid State Communications, Vol. 6, pp. 81-83.

Webster R. (1994) Gems-Their Sources, Descriptions and Identifications, 5 th ed. Ed. by P. G. Read, Butterworths, London.

Winkler E.R., Sarver J.F., Cutler I.B. (1966) Solid solution of titanium dioxide in aluminum oxide. Journal of the American Ceramic Society, Vol. 49, No. 12, pp. 634-637. 